\title{
Introduction: neoliberalism as a variety of capitalism
}

\section{What is neoliberalism?}

This book is about the neoliberal economy and how it has delivered economic inequality and stagnation. Neoliberalism is a political economic philosophy that consists of two claims, one political and the other economic. ${ }^{1}$ The political claim is that a free market laissez-faire economy is necessary for the promotion and protection of individual liberty. The economic claim is that a free market laissez-faire economy is the best way of delivering economic prosperity since it ensures economically efficient outcomes. ${ }^{2}$

There are multiple features to note about those two claims. First, free markets are central to neoliberalism, being essential for its claims about both liberty and economic efficiency. Second, given the importance of free markets in the neoliberal argument, it is easy to understand why business, wealthy interests, and high income earners all tend to strongly support neoliberalism. Third, mainstream economics is central to neoliberalism as it provides the intellectual support for the claim about markets and economic efficiency. Fourth, an important innovation of neoliberalism is its extension of economics into the political sphere via its claim about the importance of markets for liberty. That extension has been critical in widening the popular political appeal of neoliberalism.

Given the current ideological dominance of neoliberalism it is easy to take its claims for granted. However, stop to scratch the surface and serious problems quickly emerge. First, the claim about economic efficiency rests on mainstream neoclassical economics which is highly contested (even if that contest is significantly suppressed by university economics departments). Critics claim the neoclassical theoretical model is an ontologically impossible fiction which describes an economy that can never be (Albert, 2012 [1963]; Hein and Lavoie, 2016, p.262). If correct, that undermines the model's real world relevance.

Second, neoliberalism's political claims are contentious. Though it makes sense that free markets promote liberty, a market economy also needs government and behavioral restraints to function well. That points to a significant tension between liberty and free markets.

Additionally, liberty needs more than free markets, and what it needs may be at odds with free markets. In particular, liberty needs political support, which may not be forthcoming if free market outcomes are deemed unjust and unacceptable. The de jure right to liberty is unlikely to endure if it is associated with an economic system that generates outcomes that render many unable de facto to enjoy that right.

\section{The politics of the neoliberal era}

The neoliberal era is widely identified as formally beginning with the November 1980 election of Ronald Reagan in the United States (US). ${ }^{3}$ In fact, the actual transition to neoliberalism had already begun under President Carter (1977-1980) whose administration inaugurated both the deregulation and monetarist anti-inflation macroeconomic policies which have been hallmarks of the neoliberal era. 
That is a small historical detail, but it is not innocuous. Instead, it shows neoliberalism has been a bipartisan political project in the US, supported by both Republicans and the elite segment of the Democratic Party. Such bipartisanship is also true of Europe. However, there the bipartisanship came later when European Social Democratic political parties shifted right and adopted a softened version of neoliberalism, both as an electoral strategy to beat back European conservatives and because they were intellectually captured by the softened vision of neoliberalism. Politically, that softened vision is referred to as the "Third Way". In the UK it was implemented by Prime Minister Tony Blair in the 1990s. And in Germany it was implemented by Chancellor Gerhard Schröder in the 2000s.

The global bipartisan nature of the neoliberal project is extremely important. It explains why neoliberalism has been so enduring despite its awful economic consequences. Bipartisanship transformed the politics of the era, creating a politics in which the choice was between right and center-right economic policy. There was no political space for alternative policies, and everything to the left of center-right was labeled as left or extreme left, which is still the prevailing situation. That transformation has hobbled the possibility for alternative social democratic inclined policies.

Furthermore, the bipartisan pattern is paralleled in the economics profession, with parallel consequences. Thus, mainstream economics thinking was captured by the Chicago School of economics and the MIT School of economics. The former represented the right and is associated with the hard neoliberalism of the Republican Party and European conservative parties. The latter represented the center-right and is associated with the softer neoliberalism of the Democratic Party's elite and the European Third Way movement. That capture of economics has served to delegitimize and exclude alternative economic points of view which advocated different theoretical perspectives and different economic policies.

The combination of the neoliberal bipartisanship of politics and the neoliberal intellectual capture of economics explains why it has been so hard to overturn neoliberalism, despite its manifest increased inequality and tendency to economic stagnation. This capture of the top of society has trickled down to influence thinking throughout society, including even those who have been adversely impacted by neoliberalism. That has hugely compounded the difficulty of overturning neoliberalism as not only is it supported from the top by those who have benefitted from it, it is also supported from the bottom by some of those who have been adversely impacted.

Once an ideology is adopted by society and becomes dominant, it becomes akin to an article of faith. At that stage, it has to be lived through and disproved by experience before it can be rejected. Until then, both logical arguments and accumulating evidence are ignored. The former fails against faith, while the latter lacks persuasive power as the evidence is still tentative.

Even when the analytic verdict is in, the outcome remains uncertain. That is because elite interests who benefit from the ideology will fight to sustain it, while opponents of the ideology and those who have been injured by it may not converge on a shared new direction.

That situation might be said to characterize the current moment. The result can be an unhappy and politically contested period. The old regime may hang on despite the misery and discontent it has produced. Alternatively, a new regime may struggle to form, but it will suffer from lack of political strength. That can show up in the form of fractures within or counterattacks from the old regime. In a worst case scenario, it can result in irrational alliances 
between the injured and cynical elements of the elite who are intent on retaining power. In that event, politics can be diverted down the path of intolerance and scapegoating, rather than addressing the underlying causes of distress.

\section{Neoliberalism as a variety of capitalism}

The above observations on the politics of the neoliberal era have critical implications for understanding the neoliberal economy. First, they make clear that the neoliberal economy is a political creation rather than a natural order. That may sound obvious ex-post, yet it is easily lost sight of owing to economists' claims re laws of economics that parallel physical laws and economists' language of "natural" rates of unemployment, interest, and growth.

The deregulation of markets, the creation of an integrated global economy via the process of globalization, and the creation of hugely valuable property rights in the form of copyrights and patents are all the result of political interventions. That fact of political creation is not unique to neoliberalism. Rather, it applies to all economic orders, which argues for conceiving modern economies as varieties of capitalism ( VoC). Neoliberalism is a particular VoC.

Second, though the rhetoric of neoliberalism proclaims it promotes competitive "free" markets, the reality is often substantially different. Copyright and patents explicitly confer monopoly power, the antithesis of free markets. In an economic world dominated by large corporations, deregulating labor markets and weakening worker rights or facilitating corporate global mobility tends to deliver markets in which the power of the already powerful is further increased.

Third, being a political creation, neoliberalism is pushed and supported by those whose interests it advances. That tends to be corporations, the wealthy, and the highly paid.

Fourth and most importantly, if neoliberalism is a politically created $\mathrm{VoC}$, it can be politically reshaped into another VoC. Society can choose what type of economy it wants, drawing on both past experience and the exercise of current imagination. That said, the possibilities are not unlimited. Instead, they are constrained by society's current economic endowment and by basic economic principles as identified by economic theory.

Furthermore, shifting from one $\mathrm{VoC}$ to another can involve significant transition costs as prior business practices and production networks have to be re-engineered and reconfigured. Those transition costs can be large and can serve as a deterrent to change, which makes them a mechanism for "locking-in" a particular VoC (Palley, 2017/18).

The great deception of the politics of the neoliberal era is the closing down of the economic possibility space. That deception has been fed by mainstream economics via its imposition of the neoliberal model as the ideal economy. Thus, mainstream economics imagines a fictitious perfect economy (the so-called Arrow-Debreu competitive general equilibrium economy) which corresponds to the ideal neoliberal economy. That ideal is then asserted to be the unique ideal economy. Moreover, that ideal is claimed to be viable on grounds that the imagined Arrow-Debreu model is derived from the theory that mainstream economics uses to analyze the real world.

The irony is the imagined model is ontologically impossible. That impossibility, in turn, casts grave doubt on mainstream economic theory. The bitter double irony is that instead of disqualifying mainstream economic theory, the mainstream ideal has been accepted as a real world guide. Worse yet, the neoliberal era has seen governments actively trying to implement 
this flawed ideal. In effect, acting on the advice of mainstream economists, governments have paved the neoliberal road to inequality and stagnation.

\section{Deconstructing the neoliberal model}

Neoliberalism is a political economic philosophy that implicates the entirety of the political economic system. The scale and scope of its impact makes it hard to encompass and treat comprehensively. One helpful step is to deconstruct the system to identify the component parts.

Figure 1.1 provides such a deconstruction. It shows a nexus of bidirectional impacts between the four components which are identified as the neoliberal economy, economics, domestic politics, and international political economics. At the center of the system is the neoliberal economy from which ramify impacts that affect economics, domestic politics, and the international arena. The outer components also impact each other and all impacts are bidirectional, reflecting how each component affects others.

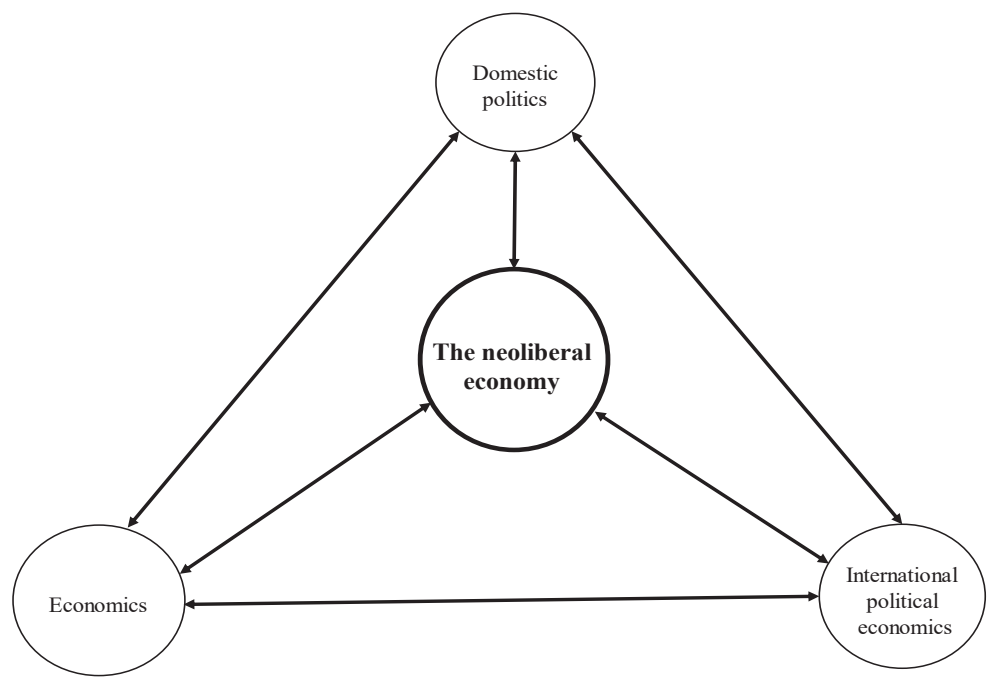

Figure 1.1 Neoliberalism and the political economic system

The neoliberal economy impacts domestic politics via its impact on the distribution of economic power, and via the economic outcomes it generates which generate political responses. The economy is itself impacted by domestic politics via economic policy which affects the structure, the rules, and the performance of the economy.

The neoliberal economy impacts economics by affecting the economic research agenda. Even more profoundly, economics impacts the neoliberal economy since the latter is built on blueprints provided and justified by economists. The ideas of economists also ramify through society, thereby impacting the perceptions, thinking, and behaviors of economic agents within the economy.

The neoliberal economy also affects and is affected by international developments. The process of globalization has been a key feature of the neoliberal era. It has transformed both 
the US domestic economy and the international economy, giving rise to a global reconfiguration of production arrangements and increased international trade (Palley, 2018).

Turning to the outer edge of Figure 1.1, economics affects domestic politics via its impact on understandings of the economy and economic policy. Conversely, politics impacts economics via its promotion of particular research agendas and points of view within economics. Just as the rise of Keynesian economics was fueled by the politics of the inter-war (1930s) and post-World War II years, so too the rise of neoliberal economics has been fueled by society's political turn to neoliberalism.

Economics also impacts the international economy via its impact on policy thinking regarding how to organize the international economy. The expansion of free trade and the liberalization of international financial capital mobility have been key developments of the neoliberal era, and those developments have been significantly influenced by the policy advice of mainstream economists. Conversely, developments in the international economy (e.g. the rise of multi-national corporations or the rise of China and the economic success of East Asian nations) feedback to influence economics.

Lastly, domestic politics are impacted by international events, and vice-versa. Globalization and the economic rise of China have had significant impacts on domestic politics, and domestic politics have had significant impacts on the international economic and political order. Thus, China was brought into the global economy by the US granting it permanent normal trading relations (PNTR) status in 2000. Now, China's astonishing rise is provoking an economic and national security backlash in US politics.

\section{The analytical complexity of neoliberalism}

The mapping in Figure 1.1 points to the complexity of neoliberalism as a political economic phenomenon. The political economics of neoliberalism consists of multiple interacting moving parts, each of which is integral to the story. That complexity makes it difficult to analyze.

The economy cannot be understood without reference to politics, and politics cannot be understood without reference to the economy. The international economy (i.e. globalization) is also an important part of the story. In the background, is the critical role of economics which has justified and designed the neoliberal model, and economics is itself subject to sociopolitical influences.

The critical role of economic ideas in the neoliberal economy is especially complicated and difficult to grasp. Economics has constructed an image (substantially based on its extensive use of mathematics) whereby it claims parallels with physics. Physics explains the natural world, while economics claims to scientifically describe the economic world.

That frame has led to the belief that mainstream economics provides "truth" about the economy. By implication, that means other economic perspectives are in error. All of that is sealed by the institution of the economics textbook. What is included therein is deemed truth: what is excluded is deemed error or, worse yet, denied of existence. ${ }^{4}$ That social reality is a central part of the difficulty in analyzing neoliberalism. As noted above, mainstream economics provides the justification and design of the neoliberal economy. However, to understand the neoliberal economy it is necessary to step outside mainstream economics, look at the economy with a different theoretical lens, and insert mainstream economics into the economy as an ingredient explaining the neoliberal economy. 
Such deconstructive thinking is totally alien to economists, given their belief that they hold the truth. It is also resisted by most of society. Elites resist it for reasons of economic selfinterest, while society as a whole resists it owing to the simplicity and comfort offered by the notion that the conventional wisdom is the truth. That societal disposition makes it hard to get a hearing for an alternative perspective, yet the record documented in this book is strongly supportive of the latter.

The left Keynesian perspective has repeatedly identified imminent major developments, and has not had to reinvent itself with each successive crisis. That contrasts with mainstream economics which has persistently failed to anticipate imminent major developments, and has had to significantly reinvent itself after each crisis in order to provide explanations of those crises.

\section{Additional perceptual complications}

In addition to the above analytic complexities, the neoliberal economy adds some further perceptual complications. First, the neoliberal economy is prone to extended asymmetric boom-bust cycles, which complicates discussion. The business cycle has lengthened, with the four business cycles of the neoliberal era (1982-1990, 1991-2001, 2001-2007, 2009-2020) averaging approximately nine years. The asymmetric aspect reflects the fact that the expansions (i.e. recovery and boom) tend to be gradual and long-lived, whereas the busts tend to be sharp and deep. That structure of asymmetrically long expansions obstructs pointing out the fundamental failings of the neoliberal model since most of the time the economy is in recovery and hope springs eternal.

Second, the cycle is significantly associated with financial markets, especially the stock market, which colors understanding. During the boom the real economy does alright, but the stock market does spectacularly. During the bust, the real economy and stock market crash together, but the stock market recovers much faster with the assistance of the Federal Reserve bank and other country central banks. That pattern tilts reporting on the neoliberal economy, as economists and the chattering class (i.e. reporters and commentators) tend to be beneficiaries of the stock market's performance.

Third, mainstream economics has difficulty with the notion of a neoliberal "regime", and that difficulty is compounded by the fact that the regime has been long-lived (it began in 1980). The idea of long-lived economic regimes is conceptually at odds with mainstream economics, which does not conceive of regimes and varieties of capitalism. For mainstream economists, there is just the market economy. Moreover, the market economy is viewed as rapidly adjusting to equilibrium, so that it quickly gravitates back to equilibrium in response to any disturbance.

However, in sharp contrast with that theoretical belief, the neoliberal economy exhibits the characteristics of a slowly deteriorating and unstable system. The busts have been getting deeper, and the recoveries have been getting weaker and slower to take hold. The busts have also needed increasingly large government intervention to put in place a floor and reset the economy. Those patterns are obscured by the long expansions and the long-lived nature of the regime. The longevity is not due to underlying good health. Instead, it is because the neoliberal economy has lived off credit and previously accumulated capital and productive structures. The reliance on credit is evidenced by the massive increase in indebtedness and debt ratios across every sector of the economy - households, non-financial corporations, the financial sector, government, and the foreign sector. 
Metaphorically, it is as if the neoliberal economy has masked its shortfalls by running up its credit card. If one starts with a good credit record and a large borrowing limit, that process can go on for a very long time, while simultaneously spawning the appearance of prosperity especially when accompanied by asset price inflation. However, the below the surface reality is very different as financial contradictions and proclivities to instability build.

Fourth, and lastly, the bipartisanship of politics and the economics profession has played into the perceptual problem by making it difficult to surface any of the above. The politicalintellectual consensus in favor of neoliberalism has been overwhelming, which has discredited critique. It has also occupied most of the public discourse space, thereby restricting visibility of critique which has been pushed to the margins of discourse.

\section{Structure and content of the book}

Figure 1.1 provides an overarching mapping of the political economics of neoliberalism. The balance of the book focuses squarely on "the neoliberal economy" which is at the center of Figure 1.1, and it also addresses the impact of "international" developments via economic globalization. To a lesser degree, the book also focuses on the linkage between "economics" and "the neoliberal economy". That additional focus is inevitable because, as noted earlier, mainstream economics is deeply implicated in the making of the neoliberal economy.

The main body of the book consists of nineteen chapters, divided into four parts titled The United States, Europe, The Global Economy, and The War of Ideas. The chapters consist of essays, written over many years, in which the analysis and (most of) the predictions have been borne out with striking accuracy. That fact speaks to the correctness of the underlying analysis, and the essays constitute a form of supportive evidence in themselves as they were written in advance of developments. That is something mainstream economists cannot claim.

Chapters 2-7 explore the evolution of the neoliberal economy in the US. That evolution has been marked by increased financial instability, increased income inequality, and the emergence of proclivity to economic stagnation.

Chapters 8-10 explore the evolution of the neoliberal economy in Europe, with an additional explicit focus on the problems generated by the introduction of the euro. The euro is the European common currency that was introduced in 1999. It was designed from scratch along neoliberal lines, in accordance with the recommendations of mainstream macroeconomic theory, and it has been the source of significant economic and political difficulties.

Chapters 11-17 explore developments associated with economic globalization. As with the euro, the design of that process has been guided by mainstream economic thinking. And as with the euro, globalization has also been the source of significant economic and political difficulties.

Chapters 18-20 discuss "the war of ideas", and it is here that the intersection between economics and the neoliberal economy is especially important. As argued earlier, the neoliberal economy is a variety of capitalism which has been politically created. Just as the economy was made in the image of neoliberalism, so too it can be remade in the image of another design. The implication is that society is engaged in a war of ideas regarding what theoretical model and vision of the economy will prevail. Economics is deeply implicated in that, and today's mainstream economics can be expected to instinctively align with the neoliberal vision owing to its ideological foundation.

How the war of ideas evolves is unpredictable. It involves the entirety of society, with the economics profession being a critical participant that occupies a strategically important place. 
The economic consequences of neoliberalism (increased inequality, financial instability, and proclivity to stagnation) are now clear - so much so that mainstream economists are looking to reverse engineer their theoretical models to allow for the possibility of such outcomes. However, the political consequences are only just beginning to work themselves out. The timescale for political developments is longer as the economic consequences must first manifest themselves, be felt, and then politically processed.

The indications are that neoliberalism has triggered a powerful and dangerous political drift to intolerant democracy, or even authoritarianism bordering on fascism. That drift is evidenced by recent political developments in Europe, which include Brexit in the UK and the ascension of far right politics in Germany, France, Italy, and Spain. In the US the drift is evident in the political rise of Donald Trump and the transformation of the Republican Party.

The drift to authoritarianism fits into the framework described in Figure 1.1, and reflects the impact of the neoliberal economy's adverse outcomes on domestic politics. However, the explication of that drift must await another book. There is too much in Figure 1.1 for a single book, showing again how difficult it is to succinctly capture the entirety of neoliberalism's impacts.

\section{Notes}

1. Palley (2012, Chapter 2) provides a fuller discussion of the history of neoliberalism and critiques thereof.

2. Economists call such outcomes "Pareto optimal". Given the initial endowment of resources, the current state of technology, and the current distribution of ownership of resources, a free market economy supposedly ensures output is produced at the lowest private economic cost and all opportunities for mutually beneficial exchange are taken up.

3. Some might argue that the formal inauguration of the neoliberal era should be identified with the May 1979 election of Margaret Thatcher as Prime Minister in the United Kingdom (UK). However, it is doubtful the global economy would have embraced neoliberalism without the US doing so, given the latter's enormous weight in all things economic. That reasoning makes the US the true political fulcrum of neoliberalism, which goes with its role as the intellectual fulcrum.

4. The view that economics parallels physics and provides truth is not restricted to mainstream economics. Many critics of mainstream economics also subscribe to that view, only they see their version of economics as being the truth. That points to an indelible need for a pluralistic economics, but this is a minority belief - especially in practice.

\section{References}

Albert, H. (1963 [2012]), "Modell-Platonismus. Der neoklassiche Stil des ökonomischen Denkens in Kristischer Beluchtung," in F. Karrenberg and H. Albert (eds.), Sozialwissenschaft und Gesellachaftsgestaltung - Festschrift für Gerhard Wesser, Berlin: Duncker und Humblot, 45-76. Translated by Arnold, D. and Maier-Rigaud, F. as "Model Platonism: Neoclassical thought in critical light," Journal of Institutional Economics, 8(3), $295-323$.

Hein, E. and Lavoie, M. (2016), "Interview with Thomas I. Palley: 'We need to confront more forcefully the neoclassical position and show the absolute impossibility of the world it describes!'," European Journal of Economics and Economic Policy, 13(3), 255-264.

Palley, T. I. (2012), From Financial Crisis to Stagnation: The Destruction of Shared Prosperity and the Role of Economics, Cambridge University Press, February.

Palley, T. I. (2017/18), "A theory of economic policy lock-in and lock-out via hysteresis: Rethinking economists' approach to economic policy," Economics: The Open-Access, Open-Assessment E-Journal, 11, 1-18.

Palley, T. I. (2018), "Three globalizations, not two: Rethinking the history and economics of trade and globalization," European Journal of Economics and Economic Policy, 15(2), 174-192. 